\title{
Neofabraea actinidiae in New Zealand kiwifruit orchards: current status and knowledge gaps
}

\author{
Joy L. Tyson*, Michael A. Manning, Kerry R. Everett and Robert A. Fullerton \\ The New Zealand Institute for Plant and Food Research Limited, Private Bag 92169, Auckland, \\ 1142, New Zealand \\ *Corresponding author: joy.tyson@plantandfood.co.nz
}

\begin{abstract}
Neofabraea actinidiae (syn. Cryptosporiopsis actinidiae) is a member of a suite of fungi associated with 'ripe rots' of kiwifruit. Although it has been recorded regularly from kiwifruit in New Zealand over the past 30-40 years, initially as 'Cryptosporiopsis sp.', there is a general lack of knowledge of this fungus. This paper provides a review of the current records and available literature on the taxonomy and biology of the organism, and assesses the knowledge gaps in the disease cycle and epidemiology of $N$. actinidiae in kiwifruit orchards. The conidia of the fungus are likely to be water borne, infect fruit during or near to flowering, and remain latent until harvest and subsequent ripening. The source of inoculum remains unknown. This review may stimulate new research into this pathogen and give insights into potential control strategies.
\end{abstract}

Keywords Actinidia, Cryptosporiopsis, host range, epidemiology

\section{INTRODUCTION}

Neofabraea actinidiae (syn. Cryptosporiopsis actinidiae) is a member of a suite of fungi associated with 'ripe rots' of kiwifruit (Actinidia spp.). It was first recorded in New Zealand as Myxosporium sp. by Ford (1971) and was subsequently referred to as Cryptosporiopsis sp. for many years (Hawthorne et al. 1982; Pennycook 1985) until being formally described as Cryptosporiopsis actinidiae in 2004 (Johnston et al. 2004).

Cryptosporiopsis anamorphs were previously recorded for several teleomorph genera, namely Neofabraea and Pezicula (Johnston et al. 2014). However, all Cryptosporiopsis species assumed the relevant teleomorph genus name following the 'one fungus, one name' classification of Norvell (2011). For 'Cryptosporiopsis' actinidiae, DNA sequencing has suggested a Neofabraea teleomorph (Johnston et al. 2014), although this has yet to be found, either in culture or in nature. Beever \& Parkes (2007) examined vegetative compatibility groups (VCG) in the $N$. actinidiae anamorph using nitrate non-utilising (Nit) mutants, finding 18 groups from 28 strains. The authors concluded that this was consistent with the re-assortment of five VCG genes during sexual recombination, which suggests that the teleomorph is a part of the disease cycle.

Neofabraea actinidiae has been recorded regularly from postharvest fruit rots of kiwifruit in New Zealand over the past 30-40 years yet there are substantial gaps in the knowledge of this fungus. In addition, many of the records in New Zealand are to be found in the 'grey' literature, e.g. unpublished reports and records, and culture collections that are unable to be accessed from outside specific institutions. This paper provides a review of the published literature and available unpublished records on the taxonomy and biology of the organism, and assesses the knowledge gaps in the disease cycle and epidemiology of $N$. actinidiae in kiwifruit orchards. 


\section{Cultural characteristics}

On potato dextrose agar (PDA), the fungus is relatively slow growing, reaching $45-50 \mathrm{~mm}$ in diameter after 2 weeks at c. $20^{\circ} \mathrm{C}$ (Johnston et al. 2004). At first, the young colonies are colourless but soon develop a conspicuous orange to bright red colourationa that often fades to pink or grey as the cultures age (Tyson pers. obs.). This colour distinguishes it from other 'Cryptosporiopsis' species with Neofabraea teleomorphs such as $N$. malicorticis (Johnston et al. 2004). The surface of the colony is covered by a glistening, slimy mass of spores. No distinct conidiomata are formed in culture, the conidia being produced on branched conidiophores developing directly from surface hyphae. Conidia are fusiform to ellipsoidal (6) 9-12 (-15) x 4-5 $\mu \mathrm{m}$, although often variable in shape. In older colonies, some conidia contain a bright orange or red pigment (Fullerton \& Tyson unpublished ${ }^{\mathrm{a}}$ ). New Zealand isolates from kiwifruit are able to grow at temperatures between 0 and $30^{\circ} \mathrm{C}$, with an optimal temperature for mycelial growth c. $20^{\circ} \mathrm{C}$. They grow very slowly at $0^{\circ} \mathrm{C}$ and are unable to grow at $35^{\circ} \mathrm{C}$ (Tyson, unpublished data).

\section{Disease symptoms on kiwifruit}

Neofabraea actinidiae is known to cause ripe rots in the green kiwifruit cultivar, Actinidia chinensis var. deliciosa 'Hayward'. Rots have occasionally been found on fruit still in storage (Brook 1991), but the fungus does not normally cause rots until 'Hayward' fruit are over-ripe. The occasional severe losses of 'Hayward' fruit in storage have been attributed to the triggering of aggressive rot development by less-than-ideal storage conditions $\mathrm{s}^{\mathrm{a}}$. When controlled atmosphere (CA) storage $\left(2 \% \mathrm{O}_{2}+5 \% \mathrm{CO}_{2}\right)$ was trialled in the early 1990 s, up to $4 \%$ of the fruit developed fungal pitting, with $N$. actinidiae being associated with over $90 \%$ of pits (Manning \& Lallu 1997). The evidence of an increase in cryptosporiopsis ripe rots under CA conditions supported earlier views that its development in storage was promoted by factors that adversely affected the physiology of the fruit ${ }^{\mathrm{a}}$.

Despite the adverse effects of storage under CA conditions, and occasional losses in conventional storage, $N$. actinidiae remained a relatively minor pathogen of stored kiwifruit (Brook 1991) until the commercial release of the goldfleshed cultivar, Actinidia chinensis var. chinensis 'Hort16A'. With 'Hort16A' fruit, significant losses to fungal pitting (very characteristic small, sunken lesions) and body rots have been sustained after 12 weeks of coolstorage. Neofabraea actinidiae and Phomopsis spp. have been found to be the main pathogens associated with this damage (Manning et al. 2003; Johnston et al. 2004; Manning et al. 2016). Normally no symptoms are expressed on unripe fruit of 'Hort16A'. As the fruit ripen, the first symptoms appear as small red-brown or black flecks on the body of the fruit, characteristically centred on lenticels, each producing a typical 'lenticel spot'. The flecks enlarge to produce depressed brown lesions 5-10 $\mathrm{mm}$ or more in diameter. When the skin of the fruit is removed, the underlying tissues have a dehydrated appearance and are light orange in coloura. Symptoms occur mostly on the sides of the fruit, although the organism may sometimes be associated with blossom end rots and, to a lesser extent, with stem end rots (Manning \& Lallu 1997). Under conditions of heavy infection, lesions can coalesce to form extensive rots on the sides of the fruit. In New Zealand, this cultivar has now been largely removed due to its susceptibility to kiwifruit canker caused by Pseudomonas syringae pv. actinidiae (Psa).

Several new cultivars of kiwifruit, including Actinidia chinensis var. chinensis 'Zesy002' (commonly known as Gold3), are now being grown commercially in New Zealand since the incursion of Psa; there is little data on the susceptibility of these to $N$. actinidiae as yet.

\section{Biology of the pathogen Host range and geographical distribution}

Neofabraea actinidiae (as Myxosporium sp.) was first recorded in New Zealand from Actinidia sp. by Ford (1971). Over the period 1971-2003 it was thought to have a limited host and geographic range, with no new hosts being recorded. More recent New Zealand records of $N$. actinidiae have 
come from orchards, and from native forests (Johnston et al. 2004; Joshee et al. 2009). In addition, the pathogen has now been identified from 17 host plant species, in 9 plant families (all woody plants) and has been recorded in Australasia, Asia, Europe and South America. All known records are listed in Table 1 . It is worth noting that a wide host range sometimes reflects a genetically diverse species and this is an area where further work is required.

\section{Biology and epidemiology in kiwifruit}

There is very little published information on the aetiology of the disease on kiwifruit and the habitat of the fungus within kiwifruit orchards, apart from in infected fruit, is unknown.
In-field infection studies of 'Hort16A' using Nit mutants have suggested that $N$. actinidiae predominantly infects the developing fruit during flowering, with a small percentage of infections occurring over the following months. The fungus then survives endophytically in the skin during fruit development (Fullerton et al. 2007).

Johnston (1994) did not detect N. actinidiae in a survey of healthy 4-, 8-, 12- and 24-month-old vine tissue (xylem, bark and leaves) of 'Hayward'. In a separate study of the fungal species most consistently associated with ripe rots of kiwifruit (Phomopsis spp., N. actinidiae and Botryosphaeria spp.), the relative incidence of each fungus within the canopy and surroundings was examined. Dead plant material was taken from

Table 1 Published records of Neofabraea actinidiae, associated plant hosts and country of origin.

\begin{tabular}{|c|c|c|c|}
\hline Plant family & Host species* $^{*}$ & Country & References \\
\hline \multirow[t]{4}{*}{ Actinidiaceae } & Actinidia arguta & New Zealand & Johnston et al. (2004) \\
\hline & Actinidia chinensis & Italy, New Zealand & $\begin{array}{l}\text { Riccioni et al. (2007); Johnston et al. } \\
\text { (2004) }\end{array}$ \\
\hline & Actinidia deliciosa & New Zealand & $\begin{array}{l}\text { Johnston et al. (2004), Chen et al. } \\
\text { (2016) }\end{array}$ \\
\hline & Actinidia indochinensis & New Zealand & Johnston et al. (2004) \\
\hline Aquifoliaceae & Ilex verticillata & Netherlands & Romero et al. (2018) \\
\hline Cupressaceae & Thuja koraiensis & South Korea & Eo et al. (2015) \\
\hline \multirow[t]{3}{*}{ Myrtaceae } & Eucalyptus diversicolor & Australia & Davison et al. (2009) \\
\hline & Kunzea ericoides & New Zealand & Joshee et al. (2009) \\
\hline & Myrceugenia ovata & Brazil & $\begin{array}{l}\text { Vaz et al. (2014) - Supplementary } \\
\text { material }\end{array}$ \\
\hline Pinaceae & Abies beshanzuensis & China (Zhejiang) & Yuan et al. (2011) \\
\hline \multirow[t]{4}{*}{ Podocarpaceae } & Dacrycarpus dacrydioides & New Zealand & Joshee et al. (2009) \\
\hline & Dacrydium cupressinum & New Zealand & Joshee et al. (2009) \\
\hline & Podocarpus totara & New Zealand & Joshee et al. (2009) \\
\hline & Prumnopitys ferruginea & New Zealand & Joshee et al. (2009) \\
\hline Proteaceae & Embothrium coccineum & Chile & Gonzalez-Teuber (2016) \\
\hline Rosaceae & Malus $x$ domestica & Brazil, New Zealand & $\begin{array}{l}\text { Bogo et al. (2018); Johnston et al. } \\
(2004)\end{array}$ \\
\hline Taxaceae & Taxus chinensis var. mairei & China (Chongqing) & $\begin{array}{l}\text { Wu et al. (2013) - Supplementary } \\
\text { material }\end{array}$ \\
\hline
\end{tabular}

*Johnston et al. (2005) also gives persimmon (Diospyros kaki) as a host, but no reference is provided for this record. 
the canopies of kiwifruit vines (bark from the trunk, residual fruit peduncles, pruning stubs), pruning remnants on the orchard floor, and from the surrounding shelterbelt species (bamboo, casuarina, cryptomeria, poplar, willow). In that study, $N$. actinidiae was not found in any of the material examined (Fullerton et al. 2003).

In New Zealand, $N$. actinidiae has been very infrequently detected in the wood of mature vines of 'Hayward' in Northland (Tyson \& Manning, unpublished data), and in trunks of 'Hort $16 \mathrm{~A}^{\mathrm{b}, \mathrm{c}}$ and 'Hayward' in the Bay of Plenty (Tyson, unpublished data). These unpublished records are all from vines suffering from 'vine decline' of various forms and as the detections of $N$. actinidiae within those vines were of far lesser frequency than other well-known pathogens, it is likely that it was a secondary coloniser. In Italy, $N$. actinidiae was isolated from leaders (main branches) showing swelling and dieback in one of five kiwifruit orchards that were displaying these symptoms (Riccioni et al. 2007). Cadophora luteoolivacea was the most commonly isolated fungus from these symptoms (all orchards) so it is likely that $N$. actinidiae was incidental and did not play an active role in causing those symptoms.

In laboratory infection trials, Hawthorne and Otto (1986) found that $N$. actinidiae was able to invade inoculated wounds on leaves of A. chinensis var. deliciosa and caused necrosis in c. $3-95 \%$ of these. Results were highly variable across different experiments. For the suite of fungi tested, which also included Phomopsis and Botryosphaeria spp., it was noted that older leaves had more necrotic lesions than young leaves.

\section{Management strategies}

Without knowledge of the basic biology of the N. actinidiae/Actinidia spp. pathosystem it is not possible to identify effective control strategies for this disease.

In vitro studies have shown the pathogen is highly susceptible $\left(\mathrm{EC}_{50}<1 \mathrm{mg} / \mathrm{L}\right)$ to thiophanate methyl, pyrimethanil and triflumizole (Bogo et al. 2018) but restrictions on the application of fungicides to fruit after flowering eliminates this as a management option in New Zealand kiwifruit.
The application of pre-harvest elicitors to kiwifruit was studied by Wurms et al. (2011). In particular, salicylic acid reduced the incidence of $N$. actinidiae ripe rots by $50-75 \%$ in highly susceptible 'Hort16A' kiwifruit. This has some potential for commercial uptake, as a systemic acquired resistance elicitor $\left(\right.$ Actigard $\left.^{\mathrm{m}}\right)$ is currently registered for reducing the symptoms of Psa in New Zealand (AgriMedia Ltd 2019).

The use of the kiwifruit-sourced volatiles, (E)-2-hexenal and ethyl hexanoate, for disease control was also investigated by Wurms et al. (2011). When used at $6 \mathrm{mg} /$ Petri plate, these inhibited $N$. actinidiae growth in vitro for 12 days. However, although both these volatiles reduced $N$. actinidiae rot when tested in a storage trial, they enhanced early ripening and induced physiological breakdown of the fruit surface, leading to increased incidence of Phomopsis spp. side rots.

Lessons from Neofabraea malicorticis, $N$. perennans and $N$. alba (bull's eye rot of apple Malus x domestica)

Information was sought on the biology of other Neofabraea species affecting perennial fruit crops due to the lack of information on the disease cycle of $N$. actinidiae within kiwifruit orchards.

Neofabraea malicorticis (syn. C. curvispora) and $N$. perennans (syn. C. perennans) are genetically the closest species to $N$. actinidiae (Pesicova et al. 2017). However, reference to biological studies on these two apple pathogens reveals few similarities between the diseases on apples and that on kiwifruit. On apple, $N$. malicorticis penetrates directly though uninjured wood (Dugan et al. 1993) to form distinctive 'fiddlestick' cankers on limbs. The cankers normally expand over only one season, although sporulation from a canker may persist for up to 3 years (Dugan et al. 1993). Neofabraea perennans requires wounds to enter the host plant and the resulting cankers enlarge over successive years (Henriquez et al. 2006).

Both species form creamy coloured spore masses on erumpent acervuli on cankers. The symptoms on fruit, commonly called bull's-eye 
rot, appear as circular, flat or slightly depressed lesions up to $25 \mathrm{~mm}$ in diameter, with a dark brown margin and a light brown or tan centre. The production of acervuli on apples infected by $N$. malicorticis and $N$. perennans is induced by chilling (Dugan et al. 1993). Cream coloured spore masses form on numerous acervuli concentrically arranged in the centres of older lesions (Spotts 2014). The fungi perennate on cankers and fallen fruit (Grove et al. 1992; Dugan et al. 1993). The teleomorph rarely forms on apple. When present they develop within the stroma of old acervuli.

Another closely related fungus, Neofabraea alba (syn. Phlyctema vagabunda) is the most common pathogen causing bull's eye rot of apple in New Zealand (Johnston et al. 2005). In contrast to $N$. perennans and $N$. malicorticis, this pathogen does not form cankers in apple trees, instead saprotrophically invades pruning wounds, dead bark and cankers caused by other pathogens (Henriquez et al. 2006). Conidia infect fruit late in the season and rots form after several months in coolstore (Everett et al., unpublished data). Bull's eye rot lesions caused by N. alba on apples are similar in appearance to those caused by $N$. perennans and N. malicorticis. Lesions are tan to light brown, circular when affecting the side of the fruit, with well-defined margins, and alternating light and dark tissue. Conidiomata can be found in old lesions (Soto-Alvear et al. 2013). Neofabraea alba can also infect through the side of the stem to cause a stem-end rot, which can eventually invade the core (Spotts 2014). As with $N$. actinidiae in kiwifruit orchards, there are gaps in the knowledge of the disease cycle and epidemiology of N. alba in apple orchards.

On kiwifruit, stem cankers are not formed by $N$. actinidiae and no spore-bearing structures have been found on vine trunks or canes, or on adjacent shelterbelt species. Unlike the diseases of apples, no fruiting bodies are formed on fruit rots either during or after cold storage, although spores have been observed within the internal necrotic tissues of fruit lesions (Fullerton, unpublished data). The natural ecological niche of the fungus in or around kiwifruit orchards remains unknown.

Differences in the pathosystems between Neofabraea malicorticis, N. perennans and N. alba in apple orchards and $N$. actinidiae in kiwifruit mean that biological information based on apple is currently of limited assistance in providing an understanding of the biological and phenological interactions of $N$. actinidiae with kiwifruit.

\section{Knowledge gaps}

There are gaps in knowledge regarding the disease cycle and epidemiology $N$. actinidiae in kiwifruit orchards. Inoculum source(s) and the mode of inoculum dispersal (wind, rain) remain unknown. There can be many rots or lenticel spots on a single fruit, which indicates a significant source of inoculum somewhere within an orchard. The pathogen has been occasionally found inside trunks and fruit stems of kiwifruit but no conidiomata or ascomata have ever been found on the vines. One possibility is that ascomata form on leaf litter and old dropped fruit, then release airborne ascospores during spring. Ascospores have never been found in New Zealand, which represents a large gap in the understanding of the disease cycle.

The timing of fruit infection by $N$. actinidiae needs to be studied further. The work of Fullerton et al. (2007) using Nit mutants was confined to three inoculation times (October, December and January). This work could be expanded to clarify infection behaviour over the entire fruit growing season and determine whether infections continue to accumulate over time.

The role of environmental factors on fruit infection and rot expression needs to be identified, as does the mechanism by which CA storage exacerbates rot formation.

A number of questions remain partially or completely unanswered:

- Does the occasional presence in the trunks of kiwifruit vines have any epidemiological significance, or is it taking advantage of other 'vine decline' organisms?

- What other plant species in the kiwifruit orchard environment are hosts for $N$. actinidiae and are conidiomata or ascomata 
formed on these?

- Is $N$. actinidiae actually a species complex? Worldwide, this fungus has a large host range and distribution (although there are very few records; Table 1).

- There has been no pathogenicity testing of $N$. actinidiae isolates across the host range. Are the various isolates host-specific, or are isolates from other reported hosts (e.g. apple, Eucalyptus) also pathogenic on kiwifruit? Considerably more work is required on $N$. actinidiae in order to understand the disease cycle and increase the available knowledge to a level that can then be used for targeted management strategies.

\section{ACKNOWLEDGEMENTS}

Zespri for funding many of the reports mentioned herein.

\section{REFERENCES}

AgriMedia Ltd 2019. New Zealand Novachem Agrichemical Manual 2018/2019. Christchurch, New Zealand, AgriMedia Ltd. $912 \mathrm{p}$.

Beever RE, Parkes SL 2007. Vegetative compatibility groups in the fungus Cryptosporiopsis actinidiae. New Zealand Journal of Crop and Horticultural Science 35(1): 67-72.

Bogo A, Comparin CC, Valdebenito Sanhueza RM, Ritschel P, Casa RT, Silva FN, Everhart SE 2018. Characterization of Neofabraea actinidiae and N. brasiliensis as causal agents of apple bull's-eye rot in southern Brazil. Canadian Journal of Plant Pathology 40(2): 229-237.

Brook PJ 1991. Botrytis stem-end rot and other storage diseases of kiwifruit - a review. Acta Horticulturae 2(297): 545-550.

Chen C, Verkley GJM, Sun G, Groenewald JZ, Crous PW 2016. Redefining common endophytes and plant pathogens in Neofabraea, Pezicula, and related genera. Fungal Biology 120(11): 1291-1322.

Davison EM, Cunnington JH, Tay FCS 2009. First record of Cryptosporiopsis actinidiae in
Australia. Australasian Plant Disease Notes 4(1): 66-67.

Dugan FM, Grove GG, Rogers JD 1993. Comparative studies of Cryptosporiopsis curvispora and C. perennans. I. Morphology and pathogenic behavior. Mycologia 85(4): 551-564.

Eo J, Lee B, Eom A 2015. First report of three species of endophytic fungi isolated from needle leaves of conifers in Korea. Korean Journal of Mycology 43(4): 272-276.

Ford I 1971. Chinese gooseberry pest and disease control. New Zealand Journal of Agriculture 122(3): 86-89.

Fullerton RA, Tyson JL, Manning MA, Meier $X$ 2003. Distribution and incidence of Phomopsis and Botryosphaeria in New Zealand kiwifruit orchards. Poster presented at: 2003 International Congress of Plant Pathology, Christchurch, New Zealand.

Fullerton RA, Rheinlander PA, Manning MA, Casonato SG 2007. Infection and rot expression by Cryptosporiopsis actinidiae and Phomopsis sp. in kiwifruit, Actinidia chinensis 'Hort16A'. Acta Horticulturae 753: 653-660.

Gonzalez-Teuber M 2016. The defensive role of foliar endophytic fungi for a South American tree. AoB Plants 8, plw050.

Grove GG, Dugan FM, Boal RJ 1992. Perennial canker of apple: seasonal host susceptibility, spore production and perennation of Cryptosporiopsis perennans in infected fruit in eastern Washington. Plant Disease 76(11): 1109-1114.

Hawthorne BT, Rees-George J, Samuels GJ 1982. Fungi associated with leaf spots and post-harvest fruit rots of kiwifruit (Actinidia chinensis) in New Zealand. New Zealand Journal of Botany 20(2): 143-150.

Hawthorne BT, Otto C 1986. Pathogenicity of fungi associated with leaf spots of kiwifruit. New Zealand Journal of Agricultural Research 29(3): 533-538.

Henriquez JL, Sugar D, Spotts RA 2006. Induction of cankers on pear tree branches by Neofabraea alba and N. perennans, and fungicide effects on conidial production on 
cankers. Plant Disease 90(4): 481-486.

Johnston PR 1994. Endophytes in apple and kiwifruit. Forty-seventh New Zealand Plant Protection Conference: 353-355.

Johnston PR, Manning MA, Meier X, Park

D, Fullerton RA 2004. Cryptosporiopsis actinidiae sp. nov. Mycotaxon 89(1): 131-136. Johnston PR, Pennycook SR, Manning MA 2005.

Taxonomy of fruit-rotting fungal pathogens: what's really out there? New Zealand Plant Protection 58: 42-46.

Johnston PR, Seifert KA, Stone JK, Rossman AY, Marvanova L 2014. Recommendations on generic names competing for use in Leotiomycetes (Ascomycota). IMA Fungus 5(1): 91-120.

Joshee S, Paulus BC, Park D, Johnston PR 2009.

Diversity and distribution of fungal foliar endophytes in New Zealand Podocarpaceae. Mycological Research 113(9): 1003-1015.

Manning M, Burdon J, De Silva N, Meier X, Pidakala P, Punter M, Billing D 2016. Maturity and postharvest temperature management affect rot expression in 'Hort16A' kiwifruit. Postharvest Biology and Technology 113: 40-47.

Manning MA, Lallu N 1997. Fungal diseases of kiwifruit stored in controlled atmosphere conditions in New Zealand. Acta Horticulturae 444: 725-731.

Manning MA, Meier X, Olsen TL, Johnston PR 2003. Fungi associated with fruit rots of Actinidia chinensis 'Hort16A' in New Zealand. New Zealand Journal of Crop and Horticultural Science 31(4): 315-324.

Norvell LL 2011. Fungal nomenclature. 1. Melbourne approves a new CODE. Mycotaxon 116: 481-490.

Pennycook SR 1985. Fungal fruit rots of Actinidia deliciosa (kiwifruit). New Zealand Journal of Experimental Agriculture 13(4): 289-299.

Pesicova K, Kolarik M, Hortova B, Novotny D 2017. Diversity and identification of Neofabraea species causing bull's eye rot in the Czech Republic. European Journal of Plant Pathology 147(3): 683-693.

Riccioni L, Manning M, Valvassori M, Haegi A,
Casonato S, Spinelli R 2007. A new disease: Leader die-back in Actinidia chinensis 'Hort16A' in Italy. Acta Horticulturae 753: 669-675.

Romero J, Raya MC, Roca LF, Agusti-Brisach C, Moral J, Trapero A 2018. Phenotypic, molecular and pathogenic characterization of Phlyctema vagabunda, causal agent of olive leprosy. Plant Pathology 67(2): 277-294.

Soto-Alvear S, Lolas M, Rosales IM, Chavez ER, Latorre BA 2013. Characterization of the bull's eye rot of apple in Chile. Plant Disease 97(4): 485-490.

Spotts RA 2014. Postharvest diseases: Bull's-Eye Rot. In: Sutton TB, Aldwinckle HS, Agnello AM, Walgenbach JF eds. Compendium of apple and pear diseases. 2nd edition. St Paul, MN, American Phytopathological Society. Pp. 78-79.

Vaz ABM, Fontenla S, Rocha FS, Brandao LR, Vieira MLA, de Garcia VDE, Goes-Neto A, Rosa CA 2014. Fungal endophyte B-diversity associated with Myrtaceae species in an Andean Patagonian forest (Argentina) and an Atlantic forest (Brazil). Fungal Ecology 8: $28-36$.

Wu L, Han T, Li W, Jia M, Xue L, Rahman K, Qin L 2013. Geographic and tissue influences on endophytic fungal communities of Taxus chinensis var. mairei in China. Current Microbiology 66(1): 40-48.

Wurms KV, Chee AA, Reglinski T, Taylor JT, Wang MY, Friel EN, Chynoweth R 2011. Postharvest volatile treatments and preharvest elicitor applications reduce ripe rot disease incidence in 'Hort16A' kiwifruit. Acta Horticulturae 913: 481-487.

Yuan Z, Rao L, Chen Y, Zhang C, Wu Y 2011. From pattern to process: species and functional diversity in fungal endophytes of Abies beshanzuensis. Fungal Biology 115(3): 197-213.

\section{ENDNOTES}

a Fullerton RA, Tyson JL 2002 (unpublished). Review of Phomopsis, Botryosphaeria and Cryptosporiopsis ripe rot pathogens 
of Hort16A, Part A: biology and control. HortResearch SPTS No. 2003/132. Auckland, New Zealand. 55 p.

b Manning MA, Casonato SG, Currie M, Nicholls P 2009 (unpublished). Reducing the threat from New Zealand vine diseases. Plant \& Food Research, SPTS No. 2384. Auckland, New Zealand. 23 p.

c Manning MA, Casonato SG, Currie M, Weber P 2010 (unpublished). Reducing the threat from New Zealand vine diseases. Plant \& Food Research, SPTS No. 3721. Auckland, New Zealand. 46 p. 